\title{
ANALISIS FAKTOR-FAKTOR PEMBENTUK KONFLIK KERJA PEGAWAI (STUDI KASUS PADA SAMSAT SE-PULAU LOMBOK)
}

\author{
Zainal Abidin ${ }^{1}$, Djoko Suprayitno ${ }^{2}$, Saparudin ${ }^{3}$ \\ ${ }^{I}$ Dosen Fakultas Ekonomi dan Bisnis Universitas Mataram, zainal.abidin@unram.ac.id \\ ${ }^{2}$ Dosen Fakultas Ekonomi dan Bisnis Universitas Mataram, djoko.suprayetno@unram.ac.id \\ ${ }^{3}$ Mahasiswa Fakultas Ekonomi dan Bisnis Universitas Mataram,saprudin@unram.ac.id
}

\begin{abstract}
This study aims to find relevant main factors of conflict in SAMSAT Offices throughout the Island of Lombok. The study design includes and confirmatory research. Total respondent in this study is 181 SAMSAT employees, but the actual data are based on 159 questionnaires. The main data collection techniques are by using questionnaires, which were previously tested for their validity and reliability in other populations. Initial stage of data analysis are correlation test, KMO and Bartlett's, anti-image correlation test, communalities, eigenvalues and the matrix components rotation. The conflict factors that are inputted in the factor analysis are 16 variables, whereas the relevant conflicts factors are only ten (10) including; workload variables, a job description, competition for resources, the dependence of the work, vagueness field tasks, the problem of status, social relationships, decision making, personnel policies and goal difference. The main conflict factors are the main job description, the competition for resources, the dependence of the work, vagueness field tasks, the problem of status, social relationships and decision making. Those variables are collected in the first factor are able to explain the variation conflict of 29.390 percent.
\end{abstract}

Keywords: The Conflict Factors and Work Conflict.

\begin{abstract}
ABSTRAK
Penelitian ini bertujuan menemukan faktor utama konflik pada kantor SAMSAT di Pulau Lombok. Desain penelitian ini adalah confirmatory research. Responden yang digunakan adalah pegawai SAMSAT sebanyak 181 orang, namun kuesioner yang kembali dan dianalisis 159 . Teknik pengumpulan data yang digunakan adalah kuesioner, dengan uji validitas dan reliabilitas. Langkah awal yang dilakukan dengan menguji korelasi, KMO dan Bartlett's, anti-image correlation dan matrix cmponents rotation. Faktor konflik yang digunakan data input ada sebanyak 16 variabel, yang relvan membentuk konflik ada 10 antara lain beban kerja, deskripsi pekerjaan, persaingan sumber,ketergantungan pekerjaan, kekaburan bidang tugas, problem status, hubungan sosial, pengambilan keputusan, kebijakan personalia dan perbedaan tujuan. Faktor utama pembentuk konflik adalah deskripsi pekerjaan, persaingan sumber, ketergantungan pekerjaan, kekaburan bidang tugas, problem status, hubungan sosial dan pengambilan keputusan. Variabel tersebut terkumpul pada faktor pertama dengan kemampuan menjelaskan konflik sebesar 29,390 persen.

Kata Kunci : Faktor Konflik dan konflik kerja
\end{abstract}




\section{PENDAHULUAN}

Manajer efektif mengalokasikan waktunya dengan proporsi 11,00 persen untuk jaringan kerja (bersosialisasi, berpolitik dan berinteraksi dengan orang-orang luar), 19,00 persen untuk manajemen tradisional (mengambil keputusan, merencanakan dan mengendalikan), 26,00 persen untuk manajemen sumber daya manusia (memotivasi, mendisiplinkan, mengelola konflik, pengisian staf dan melatih) dan 44,00 persen untuk komunikasi (mempertukarkan informasi rutin dan memproses dokumen). Manajer efektif diindikatorkan dengan kuantitas dan kualitas kerja, kepuasan serta komitmen dari bawahan (Robbins, 2003:10). Alokasi waktu dan penyelesaiannya dengan baik akan menambah efektivitas manajer terkait, termasuk jika sukses dalam mengelola konflik.

Konflik menjadi perhatian, karena konflik tidak dapat dihindarkan serta harus dikelola dalam taraf yang optimal. Organisasi tanpa konflik berdampak sama dengan konflik yang intensitasnya tinggi, yaitu kinerja yang rendah (Gibson, et.al., 1997:442). Kazimoto (2013) menegaskan bahwa pengelolaan konflik yang baik dapat menciptakan pertumbuhan organisasi, kemampuan berubah (change), beradaptasi dan bertahan. Organisasi dalam era global diindikasikan dengan turbulensi yang tinggi, sehinggi dibutuhkan pegawai yang cepat beradaptasi, kemampuan perubahan dan bertahan.

Konflik dapat dikelola dengan baik, dengan terlebih dahulu mengetahui sumbersumber konflik dalam organisasi. Penelitian ini fokus pada upaya menemukan sumbersumber konflik di SAMSAT se-Pulau Lombok, karena ada indikasi awal konflik yang tinggi dalam bekerja, baik bersumber dari dirinya, pekerjaan, organisasi dan stakeholder. Organisasi ini terdiri atas gabungan kerja dari tiga organisasi publik, bekerja dengan seragam yang berbeda serta membawa nilai-nilai anutan organisasi induknya. Beban pekerjaan yang semakin tinggi serta diharuskan menyelesaikan laporan, baik laporan harian, bulanan dan tahunan menambah tekanan dalam bekerja. Kajian awal dalam konteks confarmatory adalah mengidentifikasi sumber konflik atas dasar kajian teoritis, hasil penelitian terdahulu serta melakukan reduksi awal, terkait kesesuaian dengan fakta empiris organisasi. Batasan penting dalam riset ini adalah kajian konflik berupa konflik fungsional serta menggunakan pendekatan bahwa konflik dapat memberikan pengaruh terhadap kinerja dan efektivitas organisasi.

\section{PERUMUSAN MASALAH}

Permasalahan dalam penelitian ini adalah:

1. Apa sajakah pembentuk konflik yang relevan di SAMSAT se-Pulau Lombok?

2. Faktor-faktor utama apakah yang membentuk konflik di SAMSAT se-Pulau Lombok?

\section{TINJAUAN TEORITIS DAN KERANGKA PEMIKIRAN}

\subsection{Tinjauan Teoritis}

Robbins dan Judge (2008:172) menyatakan bahwa konflik dapat menciptakan kondisi yang kacau, tetapi satu sisi memiliki sisi positif untuk organisasi. Konflik merupakan konfrontasi karyawan atau kelompok dalam organisasi, kemungkinan implikasinya menguntungkan organisasi atau menghalangi pencapaian tujuan organisasi (Gibson, et.al., 1997:439). Fisher (2000), dalam memberikan definisi konflik "as an incompatibility of goals or values between two or more parties in a relationship, 
combined with attempts to control each other and antagonistic feelings toward each other. The incompatibility or difference may exist in reality or may only be perceived by the parties involved'. Makna secara kata, dapat dipastikan memunculkan kondisi yang tidak produktif, tetapi melalui manajemen konflik yang tepat dapat digerakkan mewujudkan tujuan organisasi.

Pertentangan, ketidakrukunan dan sejenisnya dijadikan sebagai makna konflik dalam organisasi, sehingga manajemen tradisional selalu mengidentifikasikannya sebagai kerugian. Robbins dan Judge (2008:174-175) sebagai berikut: 1) Pandangan tradisional; mempunyai pandangan atau pemikiran bahwa semua konflik berbahaya dan harus dihindari. Konflik dalam pandangan ini disinonmkan dengan kekerasan, kerusakan, irasionalitas dan hal lainnya untuk membuat konotasi negatif. Konflik juga dipandang sebagai disfungsionalitas komunikasi yang buruk, tidak adanya keterbukaan dan ketidakpercayaan antar anggota serta ketidaktanggapan manajer atas kebutuhan karyawan; 2) pandangan hubungan manusia; konflik sebagai suatu yang alamiah, tidak dihindarkan dan perlu diterima; 3) pandangan interaksionis; berpandangan bahwa konflik bukan hanya sebagai daya yang positif dalam kelompok, tetapi keniscayaan yang mutlak dalam kelompok untuk dapat berkinerja dengan efektif.

Konflik dilihat dari tingkatannya, terdiri atas interpersonal conflict, role conflict, intergroup conflict, multy-party conflict dan international conflict (Fisher, 2000). Rahim (2001:97) menambahkan skala konflik tersebut dengan intrapersonal conflict dan intragroup conflict. Konflik dapat juga dibedakan atas konflik tugas (muatan dan tujuan pekerjaan), konflik hubungan (hubungan antar personal) dan konflik proses, terkait bagaimana pekerjaan dilaksanakan (Robbins dan Judge, 2008:175).

Wibowo (2007:46) menyatakan bahwa dua puluh persen waktu manajer digunakan untuk mengelola konflik, terkait dengan identifikasi sumber sampai implikasinya atas organisasi. Diidentifikasi sumber konflik berupa penyimpangan persepsi (perceptual distortion), dendam (grudges), ketidakpercayaan (distrust) dan kompetisi atas sumber daya langka. Tiga sumber konflik awal dipastikan sebagai affective konflict. Moisoglou (2014) dalam salah satu temuannya mengidentifikasi bahwa pembentuk konflik berupa deskripsi pekerjaan. Kenneth dan Gary (2000) mengidentifikasi sumber konflik berupa persaingan terhadap sumber-sumber (competition for resources), ketergantungan pekerjaan (task interdependence), kekaburan bidang tugas (jurisdictional ambiquity), problem status (Status problem), rintangan komunikasi (Communication barriers) dan sifat-sifat individu (individual traits).

(Callister dan Wall, 1995) mengidentifikasi sumber konflik berupa 1) karakter individual, terdiri atas personality, nilai-nilai, tujuan, komitmen atas posisi, stres, kemarahan dan keinginan otonomi; 2) perspesi antar pihak, berupa persepsi antar pihak atas tujuan yang lebih tinggi, niat satu pihak bertentangan dengan lainnya, niat pihak lain yang bertentangan dengan keadilan norma, perilaku pihak tertentu berbahaya, ketidakpercayaan dan ketidakmengertian; 3) komunikasi, terdiri atas distorsi, permusuhan, ketidaksukaan, penghinaan, dan niat perilaku yang distributif; 4) perilaku, terdiri atas pengurangan hasil pihak lain, mencegah tujuan pihak lain, rendah hubungan dan perjuangan kekuasaan; 5) struktur, berupa kedekatan, kekuasaan tidak seimbang, ketergantungan kreasi, hubungan yang distributif, mempertahankan status, perlakuan istimew dan simbol; serta 6) interaksi sebelumnya, berupa kesalahan masa lalu yang disetujui, konflik masa lalu, perilaku konflik yang terkunci dan hasil konflik lainnya. Smile (2004) mengidentifikasi sumber konflik lainnya adalah kesejahteraan, pengambilan keputusan dan kuantitas dan kualitas SDM yang terbatas. Mustafa, et.al., 
(2014) mengidentifikasi sumber konflik berupa kebijakan personalia, komunikasi dan sikap karyawan.

Fisher (2000) mengidentifikasi pembentuk konflik berupa 1) konflik ekonomi (economic conflict); persaingan untuk mendapatkan sumber daya yang terbatas. Satu pihak menginginkan untuk mendapatkan lebih dan berimplikasi juga atas perilaku dalam upaya maksimalisasi kesempatan mendapatkan sumber daya; 2) konflik nilai (value conflict); meliputi ketidakrukunan dalam hal cara hidup, ideologi, preferensi, prinsip dan praktek dari keyakinannya serta 3) konflik kekuasaan (power conflict); satu kelompok berharap maksimal mempengaruhi pihak lain dalam membangun hubungan.

Sumber-sumber konflik menurut para ahli cukup konfleks, tergantung pada kajian yang dilakukan. Penelitian ini melakukan reduksi awal berupa penyaringan sumber konflik yang benar-benar mempunyai makna berbeda. Tahap awal ditemukan 25 sumber konflik, selanjutnya disaring kembali sehingga muncul 16 sumber konflik sebagai input dalam analisis faktor. Temuan atas sumber konflik yang relevan pada setiap organisasi tergolong sangat penting, karena manajemen yang tepat dapat memberikan manfaat berupa penciptaan perubahan perubahan (change), kemampuan adaptasi (adaptation) dan kemampuan bertahan (Robbins, 2003).

Gibson, et.al (1997:442) memberikan pengaruh dari konflik dengan kinerja, sebagai berikut 1) konflik sangat rendah atau tidak ada menyebabkan kinerja karyawan rendah, sehingga organisasi mempunyai kinerja rendah. Kondisi ini sama dengan konflik tinggi; serta 2) konflik dalam taraf optimal, dapat muncul sebagai pembentuk kinerja karyawan, selanjutnya kinerja organisasi yang tinggi.

\subsection{Kerangka Konseptual Penelitian}

Penelitian ini fokus pada kerja reduksi pembentuk konflik di SAMSAT SePupau Lombok. Pembentuk konflik dimunculkan dalam bentuk variabel, sehingga perlu dirumuskan indikatornya. Hasil pengumpulan teori dan penelitian terdahulu dihimpun 25 variabel pembentuk konflik, tetapi melalui proses reduksi kesamaan makna terhimpun 16 variabel. Kerangka konseptual penelitian disesuaikan dengan jenis penelitian, sebagai berikut. 


\section{Pembentuk Konflik}

\begin{tabular}{|l|}
\hline Beban Pekerjaan $\left(\mathrm{X}_{1}\right)$ \\
\hline Deskripsi Pekerjaan $\left(\mathrm{X}_{2}\right)$ \\
\hline Persaingan terhadap sumber-sumber $\left(\mathrm{X}_{3}\right)$ \\
\hline Ketergantungan pekerjaan $\left(\mathrm{X}_{4}\right)$ \\
\hline Kekaburan bidang tugas $\left(\mathrm{X}_{5}\right)$ \\
\hline Problem status $\left(\mathrm{X}_{6}\right)$ \\
\hline Rintangan komunikasi $\left(\mathrm{X}_{7}\right)$ \\
\hline Sifat-sifat individu $\left(\mathrm{X}_{8}\right)$ \\
\hline Hubungan Sosial $\left(\mathrm{X}_{9}\right)$ \\
\hline Kesejahteraan $\left(\mathrm{X}_{10}\right)$ \\
\hline Pengambilan Keputusan $\left(\mathrm{X}_{11}\right)$ \\
\hline Pengakuan Organisasi $\left(\mathrm{X}_{12}\right)$ \\
\hline Kebijakan Personalia $\left(\mathrm{X}_{13}\right)$ \\
\hline Perbedaan Tujuan $\left(\mathrm{X}_{14}\right)$ \\
\hline Kondisi Kerja $\left(\mathrm{X}_{15}\right)$ \\
\hline Konflik ekonomi $\left(\mathrm{X}_{16}\right)$ \\
\hline
\end{tabular}

Gambar 1. Kerangka Konseptual Penelitian

\section{METODE PENELITIAN}

Jenis penelitian termasuk penelitian deskriptif, dengan mengutamakan temuan atas fakta dan interpretasi yang tepat (Nazir, 2003:89). Jumlah populasi sesuai dengan jumlah pegawai SAMSAT se-Pualau Lombok sebanyak 181 orang. Data dikumpulkan dengan teknik angket.

Sumber konflik dalam penelitian ini berupa variabel (unobserved variable), sehingga perlu disusun indikatornya (observed variable). Pengukuran indikator dengan skala Likert lima ketuk, di mana hanya indikator yang valid dijadikan sebagai penjelas atas variabelnya. Kelayakan setiap indikator didukung juga dengan konsistensinya. Variabel yang memenuhi syarat kelayakan tersebut dijadikan input untuk analisis faktor, dengan tahapan 1) analisis faktor; 2) KMO; 3) bartlett's; 3) communalities; 4) eigenvalues dan 5) rotasi komponen matrik. Adapun scree plot dan komponen matrik hanya sebagai pelengkap dalam printout outputnya.

\section{Hasil Penelitian}

\section{HASIL DAN PEMBAHASAN}

Desain kerja dalam penelitian ini menggunakan data observasi (n) sebanyak 181, tetapi dengan berbagai alasan subyektif dari responden hanya kembali dan dapat diolah lebih lanjut sebanyak 159. Data observasi sebanyak 159 secara riset dan statistik dapat 
dibenarkan, karena rank data observasi dihubungkan dengan banyaknya variabel pada kisaran 90-160 responden. Faktual kerja pengumpulan data ini, maka penelitian ini masih tetap sebagai penelitian sensus.

Uji validitas dan reliabilitas angket dilakukan pada SAMSAT di Pulau Sumbawa, dengan data observasi sebanyak 57 responden, yang awalnya disebar 65 angket. Hasil uji validitas untuk seluruh indikator pada setiap variabel diperoleh $\mathrm{r}$ hitung lebih besar dari $r$ tabel $\left(\mathrm{r}_{159(0,05)}=0,254\right)$. Indikator yang disusun juga memenuhi syarat keajegan, bahwa setiap sumber-sumber konflik mempunyai koefisien reliabilitas lebih besar dari 0,60. Syarat validitas dan reliabilitas tersebut menjadi dasar yang kuat bagi peneliti untuk melakukan penghimpunan data pada subyek penelitian (pegawai SAMSAT se-Pulau Lombok). Ditemukan kriteria sumber-sumber konfliknya tergolong tinggi dan cukup tinggi, kecuali tergolong rendah pada dimensi kesejahteraan $\left(\mathrm{X}_{15}\right)$.

Proses kerja tahap pertama dengan analisis korelasi, ditemukan tiga pola hubungan antar variabel yang kuat (koefisien korelasi lebih besar dari 0,75 ), berupa: 1) rintangan komunikasi $\left(\mathrm{X}_{7}\right)$ berkorelasi tinggi dengan ketergantungan pekerjaan $\left(\mathrm{X}_{4}\right)$, koefisien korelasi 0,$750 ; 2)$ sifat-sifat individu $\left(\mathrm{X}_{8}\right)$ berkorelasi tinggi dengan kekaburan bidang tugas $\left(\mathrm{X}_{5}\right)$, koefisien korelasi 0,774 serta 3) sifat-sifat individu $\left(\mathrm{X}_{8}\right)$ berkorelasi tinggi dengan problem status $\left(\mathrm{X}_{6}\right)$, koefisien korelasi 0,762 . Berdasarkan nilai koefisien korelasi di atas, maka variabel yang dikeluarkan adalah rintangan komunikasi $\left(\mathrm{X}_{7}\right)$ dan sifat-sifat individu $\left(\mathrm{X}_{8}\right)$. Rintangan komunikasi $\left(\mathrm{X}_{7}\right)$ dikeluarkan, karena juga berhubungan tinggi dengan variabel lainnya, walaupun kurang dari $0,750\left(\mathrm{r}_{\mathrm{X} 7 \mathrm{X} 3}=\right.$ 0,$\left.620 ; r_{X 7 X 5}=0,646 ; r_{X 7 X 8}=0,720\right)$. Variabel sifat-sifat individu $\left(\mathrm{X}_{8}\right)$ yang dikeluarkan juga dengan pertimbangan yang sama, mempunyai hubungan tinggi dengan varaibel lainnya, setidaknya berhubungan sangat tinggi dengan kekaburan bidang tugas $\left(\mathrm{X}_{5}\right)$ dan problem status $\left(\mathrm{X}_{6}\right)$.

Excluding variabel yang kedua terjadi dalam tahap uji anti image correlation, yaitu kondisi kerja $\left(\mathrm{X}_{15}\right)$ dengan koefisien sebesar 0,479. Pada tahap ini dasar pengeluaran variabel, jika koefisien yang dimiliki lebih kecil dari 0,50. Hasil uji KMO dan Barlett's dengan input 13 sumber konflik adalah sumber-sumber konflik tersebut tergolong valid (koefisien KMO sebesar 0,901, lebih besar dari 0,50) dan tergolong reliabel (alpha signifikansi uji BTT's lebih kecil dari 0,05).

Jumlah faktor terbentuk sesuai dengan uji Eigenvalues sebanyak dua (2) faktor, dengan variasi untuk faktor 1 sebesar 29,390 persen dan faktor 2 sebesar 18,415 persen. Excluding sumber konflik juga terjadi pada tahap analisis rotasi komponen matrik, karena ada sumber konflik yang berkorelasi rendah $(<0,50)$ dengan faktor 1 dan 2 , berikut printoutnya: 
Tabel 1. Hasil Rotated Component Matrix

\begin{tabular}{|c|c|c|c|c|}
\hline \multicolumn{5}{|c|}{ Rotated Component Matrix ${ }^{a}$} \\
\hline & \multicolumn{2}{|c|}{ Raw } & \multicolumn{2}{|c|}{ Rescaled } \\
\hline & \multicolumn{2}{|c|}{ Component } & \multicolumn{2}{|c|}{ Component } \\
\hline & 1 & 2 & 1 & 2 \\
\hline X1.Total & .537 & .781 & .353 & .514 \\
\hline X2.Total & .792 & .289 & .565 & .206 \\
\hline X3.Total & 2.096 & .673 & .839 & .269 \\
\hline X4.Total & 2.747 & .888 & .873 & .282 \\
\hline X5.Total & 1.230 & .766 & .697 & .434 \\
\hline X6.Total & 1.537 & 1.274 & .637 & .528 \\
\hline X9.Total & 1.070 & .329 & .622 & .191 \\
\hline X10.Total & -.341 & -.158 & -.317 & -.147 \\
\hline X11.Total & .981 & .587 & .538 & .322 \\
\hline X12.Total & -.028 & -.388 & -.020 & -.278 \\
\hline X13.Total & .460 & 1.679 & .208 & .758 \\
\hline X14.Total & .928 & 2.018 & .372 & .809 \\
\hline X16.Total & .370 & -.005 & .247 & -.003 \\
\hline \multicolumn{5}{|c|}{$\begin{array}{l}\text { Extraction Method: Principal Component Analysis. } \\
\text { Rotation Method: Varimax with Kaiser Normalization. }\end{array}$} \\
\hline a. Rotation & iteratio & & & \\
\hline
\end{tabular}

Sumber: Data primer diolah (Lampiran 13).

Hasil rotasi komponen matrik di atas dijadikan dasar terhimpunya variabel dalam faktor, sebagai berikut:

1. Faktor $\mathrm{I}$, terdiri atas deskripsi pekerjaan $/ \mathrm{X}_{2}(0,565)$, persaingan terhadap sumber-sumber/ $\mathrm{X}_{3}(0,839)$, ketergantungan pekerjaan $/ \mathrm{X}_{4}(0,873)$, kekaburan bidang tugas $/ \mathrm{X}_{5}(0,697)$, problem status/ $\mathrm{X}_{6}(0,637)$, hubungan sosial/ $\mathrm{X}_{9}(0,632)$ dan pengambilan keputusan/ $\mathrm{X}_{11}(0,538)$.

2. Faktor II, terdiri atas beban pekerjaan/ $\mathrm{X}_{1}(0,514)$, kebijakan personalia/ $\mathrm{X}_{13}$ $(0,758)$ dan perbedaan tujuan/ $\mathrm{X}_{14}(0,809)$.

Variabel yang mengalami excluding pada tahap analisis rotasi komponen matrik berupa kesejahteraan/ $\mathrm{X}_{10}(0,317)$, pengakuan organisasi/ $\mathrm{X}_{12}(0,278)$ dan konflik ekonomi/ $\mathrm{X}_{16}(0,247)$. Berdasarkan analisis ini dapat ditemukan bahwa variabel-variabel atau sumber konflik yang relevan di SAMSAT se-Pulau Lombok sebanyak sepuluh dimensi, berupa:

Beban pekerjaan $\left(\mathrm{X}_{1}\right)$, deskripsi pekerjaan $\left(\mathrm{X}_{2}\right)$, persaingan terhadap sumber-sumber $\left(\mathrm{X}_{3}\right)$, ketergantungan pekerjaan $\left(\mathrm{X}_{4}\right)$, kekaburan bidang tugas $\left(\mathrm{X}_{5}\right)$, problem status $\left(\mathrm{X}_{6}\right)$, hubungan sosial $\left(\mathrm{X}_{9}\right)$, pengambilan keputusan $\left(\mathrm{X}_{11}\right)$, kebijakan personalia $\left(\mathrm{X}_{13}\right)$ dan perbedaan tujuan $\left(\mathrm{X}_{14}\right)$.

Sepuluh sumber-sumber konflik tersebut mampu menjelaskan variasi konflik kerja di SAMSAT se-Pulau Lombok sebesar 47,805 persen. Adapun sumber konflik yang paling relevan adalah dimensi-dimensi yang ada pada faktor I, terdiri atas:

Deskripsi pekerjaan $\left(\mathrm{X}_{2}\right)$, persaingan terhadap sumber-sumber $\left(\mathrm{X}_{3}\right)$, ketergantungan pekerjaan $\left(\mathrm{X}_{4}\right)$, kekaburan bidang tugas $\left(\mathrm{X}_{5}\right)$, problem status $\left(\mathrm{X}_{6}\right)$, hubungan sosial $\left(\mathrm{X}_{9}\right)$ dan pengambilan keputusan $\left(\mathrm{X}_{11}\right)$.

Sumber-sumber konflik yang paling relevan dalam menjelaskan konflik kerja di SAMSAT se-Pulau Lombok, terdiri atas tujuh sumber konflik. Tujuh sumber konflik 
tersebut mampu menjelaskan variasi konflik kerja di SAMSAT se-Pulau Lombok sebesar 29,390 persen.

\section{PEMBAHASAN}

Mengacu pada konsep teori yang dijadikan sebagai pembentuk sumber konflik di SAMSAT se-Pulau Lombok, maka empat sumber konflik yang diajukan oleh Kenneth dan Gary (2000) yang paling relevan. Empat sumber konflik tersebut adalah persaingan terhadap sumber-sumber $\left(\mathrm{X}_{3}\right)$, ketergantungan pekerjaan $\left(\mathrm{X}_{4}\right)$, kekaburan bidang tugas $\left(\mathrm{X}_{5}\right)$, problem status $\left(\mathrm{X}_{6}\right)$. Penelitian Moisoglou, et.al (2014) mengidentifikasi sumber konflik berupa deskripsi pekerjaan. Wahyudi (2013) berupa hubungan sosial antar pegawai dan Smile (2014) berupa pengambilan keputusan.

Tiga sumber konflik lainnya yang relevan dengan hasil penelitian ini, tetapi tidak termasuk sebagai faktor yang paling relevan adalah riset Athanasios, et.al (2014) dengan sumber konflik perbedaan tujuan, Wahyudi (2013) berupa beban pekerjaan dan Mustafa (2014) kebijakan personalia. Berbagai sumber konflik, terutama yang sifatnya paling relevan perlu mendapatkan perhatian yang utama, untuk dikelola, karena memberikan variasi konflik kerja yang tinggi di SAMSAT se-Pulau Lombok.

SAMSAT se-Pulau Lombok perlu dikelola sebagai organisasi yang mandiri, di mana diberikan kewenangan dalam mengelola organisasi dalam makna yang luas. Implikasinya harus ada manajemen puncak, sebagai pengambil keputusan yang membawahi manajerial tiga unit kerja yang ada (UPTD PPDRD, Kepolisian dan Jasa Raharja). Hal ini ditegaskan, karena sumber konflik yang ditemukan relevan dengan tugas-tugas manajerial, terutama tugas MSDM dalam organisasi.

Dimensi deskripsi pekerjaan dirancang oleh internal organisasi, bukan oleh masing-masing organisasi yang membawahinya. Hal ini penting agar tiga unit kerja tersebut sebagai satu satuan dari organisasi SAMSAT se-Pulau Lombok, bukan hanya sebagai tempat kerja satu atap, tetapi dengan manajemen yang terpisah. Deskripsi pekerjaan dibangun dari keluaran yang hendak diarahkan oleh SAMSAT se-Pulau Lombok, sehingga perlu dilakukan analisis jabatan terlebih dahulu.

Deskripsi pekerjaan dapat dinyatakan sebagai produk langsung dan pertama dari hasil analisis jabatan (Simamora, 2004:109). Pengelolaan yang lebih baik atas deskripsi pekerjaan, merupakan upaya untuk menghindari ketidakjelasan pekerjaan (Moisoglou, et.al., 2014). Manajemen yang perlu diterapkan adalah melakukan perbaikan atas deskripsi pekerjaan.

Simamora (2004:109) memberikan saran berupa pedoman dalam membuat deskripsi pekerjaan, yaitu 1) terfokus pada muatan pekerjaan (cara pekerjaan dikerjakan oleh pemangku jabatan); 2) menentukan keluaran pekerjaan (penentuan indikator kuantitatif dari hasil yang diharapkan; 3) menghindari bahasa yang kabur; 4) membuat peringkat komponen pekerjaan dalam urutan signifikansi dan waktu yang dicurahkan; 5) ada deskripsi yang terpisah pada setiap jabatan. Pihak internal SAMSAT se-Pulau Lombok yang mengetahui keluaran yang dibutuhkan dan hasil yang diharapkan pada setiap unit kerja, agar produk yang dihasilkan tepat.

Adanya deskripsi pekerjaan yang baik, maka secara otomatis akan memudahkan dalam memberi jabatan pada setiap personel. Dapat ditentukan dengan jelas pengetahuan, keahlian, kemampuan serta karakteristik lainnya yang dibutuhkan untuk dapat menyelesaikan pekerjaan dengan baik. Dapat dinyatakan bahwa deskripsi pekerjaan yang baik menjadi awal yang baik dari proses internal dalam organisasi, meliputi klarifikasi tanggung jawab, rekrutmen dan lainnya. 
Kondisi ini yang belum ada dalam jabatan yang ada di SAMSAT se-Pulau Lombok, bahwa para karyawan bekerja berdasarkan aturan yang ada di organisasi masing-masing. Untuk masa depan, maka diperlukan satu manajemen puncak, sehingga ada keselarasan dalam mengelola organisasi. Pengelolaan ini dapat dinyatakan sebagai upaya untuk menghindari konflik, dalam riset Moisoglou, et.al., (2014) diharapkan oleh 62,00 pegawai.

Persaingan terhadap sumber-sumber; muncul sebagai salah satu pembentuk yang paling relevan. Terapan manajemen yang perlu dilakukan adalah alokasi sumberssumber harus atas dasar kesesuaian beban pekerjaan dan hasil kerjanya. Pihak manajemen perlu melakukan analisis yang mendalam atas deskripsi pekerjaan untuk mengetahui beban kerja dan secara priodik melakukan penilaian atas hasil kerja. Dasar tersebut digunakan untuk melakukan alokasi sumber daya, bukan sebatas alokasi semata. Pengelolaan yang demikian relevan dengan strategi penciptaan persaingan antar personal dan antar unit kerja, hanya yang mampu merealisasikan tugas dengan baik mendapatkan alokasi sumber daya yang terbanyak.

Ketergantungan pekerjaan; dalam setiap organisasi tidak dapat dihindari, karena setiap individu mempunyai keahlian dan keterampilan tertentu, organisasi dibangun dari beberapa sub unit kerja, di mana masing-masing mempunyai pekerjaan tertentu. Kejelasan pekerjaan akan memberikan kemudahan tugas masing-masing, sehingga disadari bahwa hasil kerjanya dibutuhkan dengan kuantitas, kualitas dan ketepatan waktu, karena akan menentukan spesifikasi hasil akhir. Kebiasaan bekerja bersama, diterapkan melaluli kolaborasi antar personel dalam unit kerja atau antar unit kerja sangat dibutuhkan. Kolaborasi menjadi terapan manajemen yang disukai oleh pegawai dalam pengelolaan konflik (38,10 persen). Dalam hal ini ada peran semua pihak dalam memberikan solusi untuk perbaikan.

Kekaburan bidang tugas dapat dihindari dengan cara penyusunan deskripsi pekerjaan yang baik. Fakta adanya bidang tugas yang bias (ambigui), maka perlu ada pusat informasi yang akan bertugas untuk memberikan pekerjaan tertentu pada unit kerja tertentu. Misalnya jika ada kesalahan dalam produk akhir, maka bagian ini melakukan evaluasi unit kerja yang bertanggungjawab dalam melakukan perbaikan. Unit kerja berupa pemberi informasi dalam organisasi ini dapat dijadikan sebagai pemberi mediasi langsung atas keputusan yang dibuat.

Problem status dapat menjadi ego individual dan unit kerja, menunjukkan sikap mendominasi satu pegawai pada pegawai lain, unit dengan unit lain serta keengganan dan meminta bantuan pada rekan atau unit kerja lain. Kesadaran bahwa seluruh pegawai dan unit kerja sebagai bagian dari organisasi, perbedaan kemampuan dan skil harus ditumbuhkan. Persaingan dalam menunjukkan hasil kerja tidak secara negatif, tetapi saling mendukung untuk mendapatkan hasil yang terbaik. Hal ini berdampak pada kinerja organisasi, yang berimplikasi pada alokasi sumber daya yang lebih tinggi. Kebiasaan kerja sama, saling membutuhkan menjadi perhatian utama dari pihak manajemen. Upaya yang diterapkan adalah kolaborasi dari semua pihak, bahwa setiap personel mempunyai kontribusi yang sama pada organisasi.

Hubungan sosial pada prinsipnya adalah kebutuhan semua pegawai, sehingga harus diupayakan untuk direalisasikan dengan cara yang baik oleh pihak manajemen. Kegiatan di luar kerja dibutuhkan, seperti olah raga bersama, kegiatan sosial bersama atau kegiatan lain yang telah diatur oleh pemerintah. Misalnya pada setiap Jum'at ada kegiatan olah raga, setiap jam tertentu dilakukan istirahat untuk sholat bagi yang muslim, seluruhnya harus digunakan dengan maksimal untuk menciptakan perasaan sebagai bagian organisasi yang mempunyai posisi sosial yang sama, tanpa 
memperhatikan kepangkatan dan unit kerja. Saling berkompromi dapat menjadi solusinya, diterapkan dengan saling memberi dalam hubungan sosial yang harmonis (Chinaka, N.J., dan Grace, M.O., 2014). Dapat juga diterapkan upaya yang diajukan oleh Smith, G., Michaud, G., Reynoso, S dan Struss, P (2014), yaitu dengan menciptakan komunikasi, kesadaran, pembelajaran dan kerjasama.

Pengambilan keputusan dalam organisasi merupakan suatu yang vital, di mana personel yang melakukan keputusan harus mempunyai pengetahuan tentang kondisi internal dan eskternal organisasi. Dalam waktu singkat, maka upaya untuk bekerja sama antar kepala unit yang ada di SAMSAT se-Pulau Lombok sangat diperlukan. Komunikasi bukan hanya diperuntukkan bagi staf, tetapi juga level pimpinan pada setiap unit. Berhubungan dengan hal ini, kebijakan lain yang dapat diupayakan adalah administrasi yang transparan, pertemuan yang sifatnya regional, menerapkan sistem feedback yang cepat, membangun pengambilan keputusan dalam organisasi (Smile, 2014).

Kajian di atas untuk sumber-sumber konflik yang mempunyai relevansi yang utama atas pembentukan konflik kerja di SAMSAT se-Pulau Lombok. Sumber konflik lainnya adalah beban pekerjaan, kebijakan personalia dan perbedaan tujuan. Pihak manajemen pada setiap kerja harus mampu memprediksi kuantitas atau beban kerja organisasi. Pengelolaan selanjutnya adalah melakukan alokasi sumber daya yang ada di internal organisasi (SAMSAT se-Pulau Lombok). Apabila sumber daya yang dimiliki, terutama sumber daya manusia dan sistem kerja, maka perlu meminta pemenuhannya dari manajemen pusat. Kebijakan personalia menjadi sangat penting dalam kajian ini, dilakukan oleh internal SAMSAT se-Pulau Lombok jika mempunyai kewenangan, jika tidak maka dilakukan permintaan alokasi. Satu sisi perbedaan tujuan dapat diatasi dengan membina komunikasi antar personel dan divisi yang ada dalam organisasi.

Simpulan penelitian adalah:

\section{SIMPULAN}

1. Sumber konflik yang relevan sebagai pembentuk konflik kerja di SAMSAT sePulau Lombok berupa Beban pekerjaan, deskripsi pekerjaan, persaingan terhadap sumber-sumber, ketergantungan pekerjaan, kekaburan bidang tugas, problem status, hubungan sosial, pengambilan keputusan, kebijakan personalia dan perbedaan tujuan. Seluruh sumber konflik ini mampu menjelaskan konflik kerja di SAMSAT se-Pulau Lombok sebesar 47,805 persen.

2. Sumber konflik yang paling relevan adalah deskripsi pekerjaan, persaingan terhadap sumber-sumber, ketergantungan pekerjaan, kekaburan bidang tugas, problem status, hubungan sosial dan pengambilan keputusan. Sumber-sumber konflik ini mampu memberikan penjelasan variasi konflik kerja di SAMSAT se-Pulau Lombok sebesar 29,390 persen. Sumber konflik ini diberikan nama non obyektivitas pekerjaan. 


\section{DAFTAR PUSTAKA}

Athanasios, L., et.al (2014). The Sources of Conflict in Professional Basketball Teams The Case of Greece. International Journal of Scientific Research. Vol. 3. No. 1. p.216-218.

Baharuddin, (2012). Konstelasi Konflik dalam Lembaga Pendidikan: sebuah Telaah Kritis. Jurnal el-Hikmah Fakultas Tarbiyah UIN Maliki, Malang.

Callister, R.R. dan Wall, J.A., (2009). Conflict and Itis Management. Journal of Management. vol 21. No.3. p. 515-558.

Comboh, M.A., (2014). Examine Conflicts in Industrial Relations \& Collective Bargaining Context and its Impact on Workers \& Organization Performance. Academy of Contemporary Research Journal. Vol. III, No. 1. p.14-25.

Dessler, G., (1997). Manajemen Sumber Daya Manusia, Jilid 1. Jakarta: PT. Prenhallindo.

Emory C.W., dan Cooper, D.R., (1997). Metode Penelitian Bisnis, Jakarta: PT. Gelora Aksara Pratama.

Ferdinand, A., (2002). Structural Equation Model Dalam Penelitian Manajemen. Semarang: BP. UNDIP.

Fisher, R., (2000). Sources of Conflict and Methods of Conflict Resolution. The American University.

Ghozali, I., (2013). Aplikasi Analisis Multivariate dengan Program SPSS. Semarang: Badan Penerbit Universitas Diponegoro.

Gibson L. James, dkk., (1997). Organisasi; Perilaku, Struktur, Proses. Jakarta: Bina Aksara.

Gitosudarmo, I., dan Sudita I.N., (2001). Perilaku Keorganisasian. Yogyakarta: BPFE.

Hartanto, F.M., (2009). Paradigma Baru Manajemen Indonesia; Menciptakan Nilai dengan Bertumpu pada Kabajikan dan Potensi Insani. Bandung: PT. Integre Quadro.

Mcleod R., Jr., dan Schell, G., (2001), Sistem Informasi Manajemen. Jakarta: PT. Indeks.

Meihartono, M.J., (2010). Analisis Faktor-Faktor Yang Membentuk Perilaku Kerja Pamong Belajar (Studi Kasus Pada Sanggar Kegiatan Belajar Dan Balai Pengembangan Kegiatan Belajar Masyarakat Provinsi Nusa Tenggara Barat). Tesis Program Magister Manajemen Pascasarjana Universitas Mataram. Mataram. 
Moisoglou, I., et.al, (2014). Conflict Management in a Greek Public Hospital: Collaboration or Avoidance. International Journal of Caring Sciences. Vol 7. p. 75-82.

Muhidin, S.A. dan Abdurahman, M., (2007). Analisis Korelasi, Regresi dan Jalur dalam Penelitian. Bandung: CV. Pustaka Setia.

Mustafa, G., et.al., (2014). Analytical Study on Employee's Conflicts, Its Effects and the Prospective Solutions in Knitwear Industry of Faisalabad. Asian Journal of Business Management. Vol. 6. No. 2. p. 104-110.

Nazir, M., (2003). Metode Penelitian. Jakarta: Ghalia Indonesia.

Omisore, B.O., dan Abiodun, A.R., (2014). Organizational Conflicts: Causes, Effects and Remedies. International Journal of Academic Research in Economics and Management Sciences. Vol. 3. No. 6. p. 118-137.

Rahim, A.M., (2001). Managing Conflict in Organizations. USA: Greenwood Publishing Group, Inc.

Robbins, P.S., (2003). Perilaku Organisasi. Jakarta: PT. Indeks.

Robbins, P.S. dan Judge, A.T., (2008). Perilaku Organisasi. Jakarta: PT. Indeks.

Sahrun, (2011). Analisis Faktor-faktor yang Membentuk Kualitas Pelayanan pada Badan Perpustakaan Arsip dan Dokumentasi Daerah Kabupaten Lombok Tengah. Tesis Program Magister Manajemen Pascasarjana Universitas Mataram. Mataram.

Sedarmayanti, (2014). Manajemen Sumber Daya Manusia, Reformasi Birokrasi dan Manajemen Pegawai Negeri Sipil. Bandung: PT.Refika Aditama

Simamora, H., (2004). Manajemen Sumber Daya Manusia. Yogyakarta: STIE YKPN.

Smile, D., (2014). Conflicts and Job Performance: Towards an Effective Diagnosis And Management Strategies. International Journal of Economics, Commerce and Management. Vol. II., No. 6. p. 1-21.

Supardi, (2012). Analisis Faktor-faktor yang Membentuk Kinerja Kepala Sekolah di Kecamatan Pujut dan Kecamatan Praya Barat Kabupaten Lombok Tengah. Tesis Program Magister Manajemen Pascasarjana Universitas Mataram. Mataram.

Umar, H., (2008). Metode Penelitian untuk Skripsi dan Tesis Bisnis. Jakarta: Raja Wali Press.

Wahyudi (2006). Manajemen Konflik dalam Organisasi. Bandung: Alfabeta. 
Wahyudi, (2013). Manajemen Konflik Dalam Meningkatkan Produktivitas Organisasi; Studi Kasus Pada Pusat Pengembangan Penataran Guru Teknologi di Malang Jawa Timur. Disertasi. Universitas Pendidikan Indonesia. e-library.

Widarjono, A., (2010). Analisis Statistika Multivariat Terapan. Yogyakarta: UPP STIM YKPN.

Wibowo (2007). Manajemen Perubahan. Jakarta: PT. RajaGrapindo Persada.

Wirawan (2007). Budaya dan Iklim Organisasi; Teori Aplikasi dan Penelitian. Jakarta:Salemba Empat. 